\title{
Обґрунтування систем технологій збирання біологічного врожаю конопель
}

\author{
В.В. Шевчук ${ }^{1}$, В.О. Шейченко ${ }^{2}$, С.Ю. Проценко ${ }^{3}$, В. М. Гак ${ }^{3}$, М.М. Кордубан ${ }^{3}$ \\ 1 Уманський національний університет садівництва (м. Умань, Україна) \\ email: Shevchuk1611@ukr.net; ORCID: 0000-0001-8305-4714 \\ 2,3 Полтавська державна аграрна академія (М. Полтава, Україна) \\ email: ${ }^{2}$ vsheychenko@ukr.net
}

\begin{abstract}
Досліджено шляхи підвищення ефективності механізованих технологічних процесів збирання усього обсягу біологічного врожаю конопель та льону завдяки використанню стрічкових накопичувачів.

Запропоновано спосіб фрормування валка конопле стеблової маси на стрічку і волочіння їі разом з валком до краю поля, що уможливлює суттєве підвищення ефективності механізованих процесів збирання і подальшого перероблення усього біологічного врожаю конопель, льону та інших культур.

Розроблено сукупність змістів основних варіантів (розгалужень) систем технологій збирання усього біологічного врожаю конопле стеблової маси на стрічкові накопичувачі, якими враховано технічні, технологічні та економічні передумови реалізації основних технологічних операцій, властивих відповідним технологіям.

Запропоновано спосіб формування на стерні валків із заданою масою стебел на одному погонному метрі. Суть способу полягає в тому, що скошену конопле стеблову масу укладають у вигляді валка на стрічку, яку відпускають зі швидкістю меншою швидкості руху жнивного агрегату. Завдяки цьому уможливлюється накопичення на незначній частині поля по кінцях гону усього обсягу врожаю конопле стеблової маси.

Запропоновано якісно новий технологічний процес, у якому не молотарка (комбайн) із засобами її технологічного обслуговування переміщується по полю з метою завантаження конопле стебловою масою, а конопле стеблова маса у вигляді валка подається до молотарку. Завдяки реалізації відміченого технологічного процесу уможливлюється операції обмолочування насіннєвої частини врожаю, обрізання листя від стебел, формування стебел з метою їх подальшої переробки у тресту здійснювати напівстаціонарними комплексами машин на краю поля.
\end{abstract}

Ключові слова: промислові коноплі, збирання конопель, фрази стиглості, стрічкові накопичувачі.

Постановка проблеми. Коноплярство як галузь землеробства, нараховує декілька тисячоліть. Здатність формувати волокно в стеблах та олію в насінні визначили коноплі незамінними на всіх етапах розвитку суспільства, починаючи 3 давніх-давен і до сьогодення.

Сучасний розвиток галузі коноплярства має ряд особливостей. Зокрема, науковими установами і практикою коноплевиробництва досягнуто значних успіхів, що заслуговують на увагу та узагальнення. Створено сорти нового покоління різних напрямів використання та сортові технології їх вирощування. Зараз в Україні промислові коноплі вирощують (рис. 1) в основному для одержання насіння. У технологіях збирання акцент зроблено на використання сільськогосподарської техніки загального призначення, а у переробці на вироблення короткого волокна [1-2].

Аналіз останніх досліджень. Відомо, що коноплі мають дві фрази стиглості, - технічну і біологічну. Період технічної стиглості конопель характеризується завершенням приросту рослин у висоту, накопиченням урожаю соломи і волокна, фрормуванням якісних властивостей волокнистої продукції. Цей період співпадає з дозріванням поодиноких насінин у нижній частині суцвіть однодомних рослин. Для біологічної стиглості конопель характерне повне дозрівання насіння. Тривалість між технічною і біологічною стиглістю сортів конопель становить, у середньому 25-35 діб і залежить від погодних умов у період дозрівання насіння та біологічних властивостей популяції [1, 3].

На підставі того, що для конопель характерні два періоди стиглості, застосовують відповідно і два строки збирання культури - на волокно (зеленець) та насіння i волокно (двобічне використання) [4].

Своєчасне збирання конопель уможливлює високу якість продукції і рентабельність коноплярства. Несвоєчасне раннє збирання призводить до недобору врожаю, а запізнення зі збиранням - до значних втрат насіння і волокнистої продукції та зниження їх якості. Найвищу урожайність насіння, соломи і волокна при двобічному 
використанні забезпечує збирання однодомних конопель у період дозрівання $75 \%$ насіння у більшості рослин. Більш раннє збирання недоцільне, оскільки призводить до недобору 18-54\% урожаю насіння, а затримання строків збирання збільшує втрати до 24-61\% [1, 5].

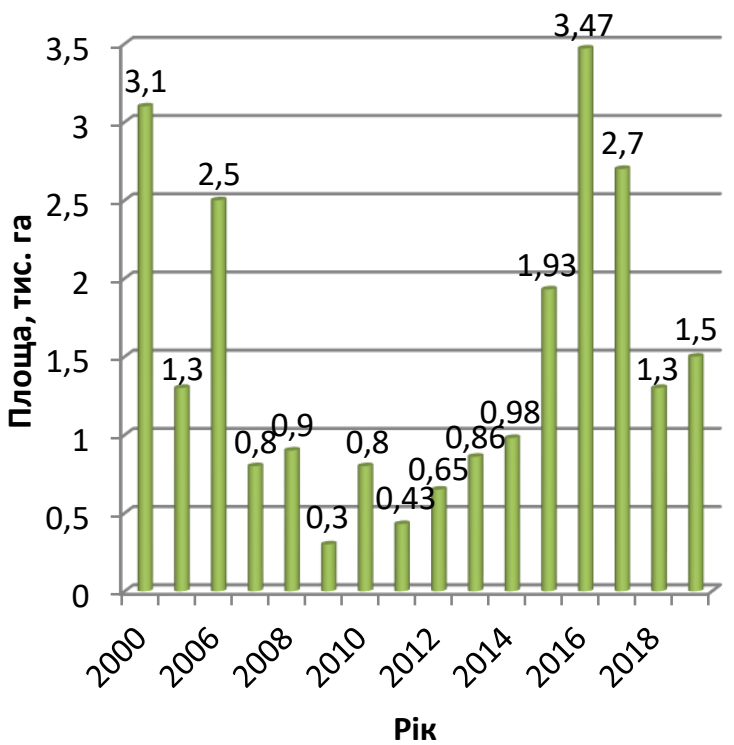

Рис. 1. Діаграма змінення площ посіву промислових конопель в Україні

Зеленцеві посіви розпочинають збирати у період достигання 10-50\% насіння, коли завершується фрормування урожаю та якості волокна.

У сучасних умовах господарювання для збирання конопель двобічного використання застосовують сільськогосподарську техніку загального призначення з відокремленням основної продукції (насіння і волокнистої сировини) у кілька етапів.

На першому етапі збирають насіннєву складову урожаю, застосовуючи зернозбиральні комбайни різних виробників. Перевагу надають комбайнам з більшою висотою підйому жатки 3 клавішним типом соломотряса [6].

Збирання стеблостою конопель здійснюють із застосуванням сільськогосподарської техніки загального призначення: косарки (жниварки), граблі, котки, прес-підбирачі. Порядок використання техніки та інтенсивність дій робочих органів на конопляну сировину залежить від напрямів подальшого її використання [7].

Розвиток технологічних процесів виробництва конопель і льону все гостріше потребує нових техніко-технологічних рішень, які б уможливили розв'язання проблеми ефективності подальшої механізації виробництва цих технічних культур у цілому. Очевидно аналогічний стан справ можна спостерігати і у виробництві інших видів сільськогосподарських культур з високим рівнем механізації праці.
Метою даної роботи $є$ підвищення ефективності систем виробництва конопель завдяки розробленню механіко-технологічних передумов вдосконалення основних технологічних операцій, пов'язаних із збиранням усього біологічного врожаю конопель.

Головними шляхами досягнення мети $€$ пошук принципово нових технологічних прийомів і технічних засобів для підвищення ефективності технологій збирання усього біологічного врожаю конопель (насіння, волокнистої сировини, костри, конопле стеблової маси для медичних потреб).

Результати досліджень. Ідеї формування валка конопле стеблової маси на стрічці і волочіння їі разом з валком до краю поля, на якому здійснюються збиральні роботи, виникли за результатами багаторічних досліджень і спостережень валкоутворення за умов роботи жнивних машин. Суть її полягає у тому, що при скошуванні конопле стеблової маси жниваркою, зрізані стебла укладають у вигляді безперервного валка на стрічку, яка попередньо під нього (валок) підстелена. Останню розстеляють одночасно з процесом формування валка (рис. 2, а) або попередньо вздовж гону (рис. 2, б). У процесі завантаження стрічка може бути нерухомою щодо ґрунту або ковзати по стерні разом з конопле стеблової масою, що надходить на неї. За таких умов слід зазначити, що в разі коли стрічка ковзає по стерні зі швидкістю меншою швидкості руху жниварки, відбувається надзвичайно важливе з точки зору процесу валкоутворення явище збільшення маси погонного метра валка внаслідок зменшення його довжини. Реалізація цього явища має велике практичне значення особливо в разі фрормування валків із заздалегідь заданою масою стебел на одному погонному метрі. Так завдяки регулюванню швидкості руху стрічки щодо рухомої валкової жниварки, можна в широких межах плавно змінювати масу одного погонного метра валка, який формується не тільки на стрічці, а й на стерні. Відмітимо, що це можна здійснити за незмінної ширини робочого захвату жнивного агрегату.

Сформований на стрічці валок можна транспортувати (волочити) разом зі стрічкою уздовж гону (не обов'язково прямолінійного) до місця обмолоту або вивантаження конопле стеблової маси. Це означає, що стрічковий накопичувач можливо застосовувати як спеціальний вид безколісного транспортного засобу для переміщення валка конопле стеблової маси і т.п. матеріалів в межах поля. Відмітимо можливість накопичення і транспортування валка конопле стеблової маси на стрічковому накопичувачі з тим, щоб висловити припущення (гіпотезу) про доцільність застосування цієї ідеї для удосконалення способів збирання конопель. 


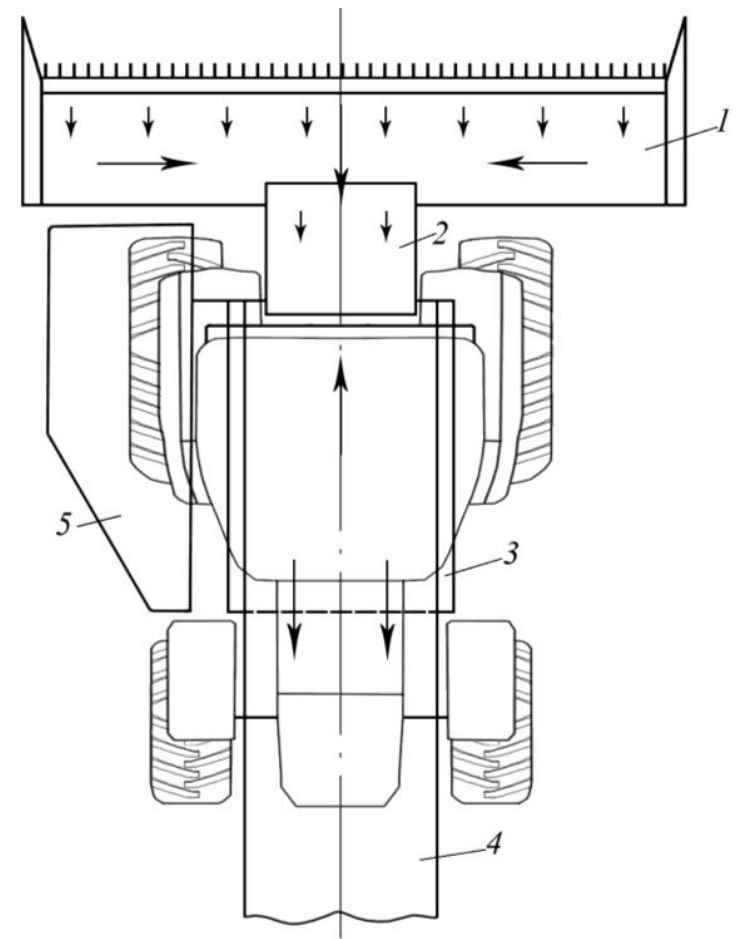

a

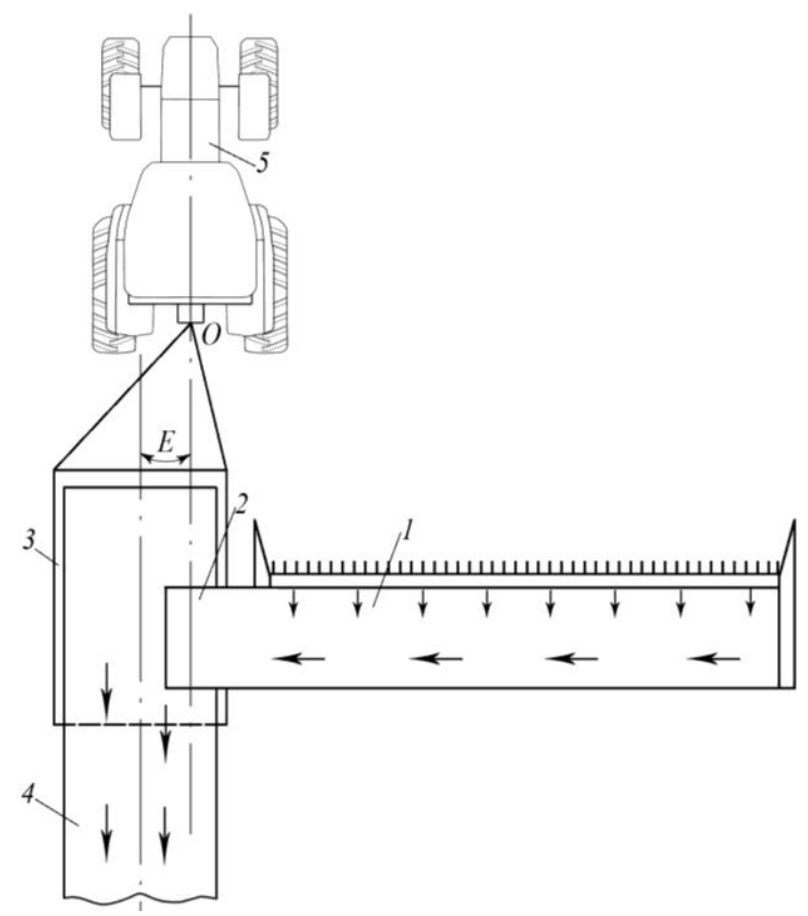

6

Рис. 2. Схема формування валка на стрічковому накопичувачі:

а) розстеленому в процесі формування валка; б) попередньо розстеленому: 1 - жнивна система, 2 - транспортер конопле стеблової маси, 3 - рулон стрічки, 4 - валок конопле стеблової маси, 5 - мобільна молотильна система (зернозбиральний комбайн)
За умов формування на стрічковому накопичувачі валка конопле стеблової маси з повністю дозрілим насінням пріоритет доцільно надавати саме цьому направленню.Після відділення насіння стеблова маса володіє значним потенціалом щодо подальшого перероблення. Валок можливо сформувати на стрічці за умов скошування дозрілої конопле стеблової маси (рис.3). Тоді реалізується сценарій використання її на волокно та збирання листостеблової маси. Надалі можна уявити, що стрічку з боку її завантаження згортають в рулон, поступово підтягуючи разом 3 валком і перевантажуючи конопле стеблову масу з стрічки в нерухомий комплекс машин. В залежності від технології переробки (волокно, насіння, листостеблова маса, стебла для трести) комплекс формується напівстаціонарними машинами, які можуть здійснювати обмолочування насіння, обрізання листя від стебел, формування стебел з метою їх подальшої переробки у тресту.

У цьому полягає сутність якісно нового технологічного процесу, що відрізняється тим, що не молотарка (комбайн) із засобами її технологічного обслуговування переміщується по полю 3 метою завантаження конопле стебловою масою, а конопле стеблова маса у вигляді валка подається до молотарку, що розташована на краю поля. Крім цього на краю поля можливе подальше перероблення конопле стеблової маси в разі коли насіннєву частину вже зрізано і обмолочено. Такі технологічні прийоми мають ряд істотних переваг перед традиційними способами збирання конопель.

Запропонований спосіб накопичення конопле стеблової маси на стрічку може бути покладено в основу принципово нового способу формування на стерні валків із заданою масою стебел на одному погонному метрі. Суть цього способу полягає в наступному. Конопле стеблову масу жниваркою з стрічко протяжним механізмом укладають у вигляді валка на стрічку, яку відпускають зі швидкістю меншою швидкості руху жнивного агрегату. У кінці гону (не доходячи до краю 200 ... 250 м) стрічку починають підтягувати до жниварки, не припиняючи руху жнивного агрегату. Раніше накопичені стебла, що надходять із стрічки, вивантажують на стерню, поєднуючи їх з потоком свіжоскошених стебел. До моменту надходження (пересування) до кінця гону жниварка і стрічка повністю звільняються від конопле стеблової маси. За таких умов порожня стрічка згортається в рулон. Отже, після вивантаження конопле стеблової маси 3 стрічки на стерню можна здійснювати черговий робочий прохід жнивних агрегатів.

За такого способу фрормування валків увесь обсяг конопле стеблової маси зосереджується по кінцях гону на незначній частині поля (рис. 3). Надалі ці валки можуть бути або обмолочено комбайнами звичайними або згаданим вище способом. 


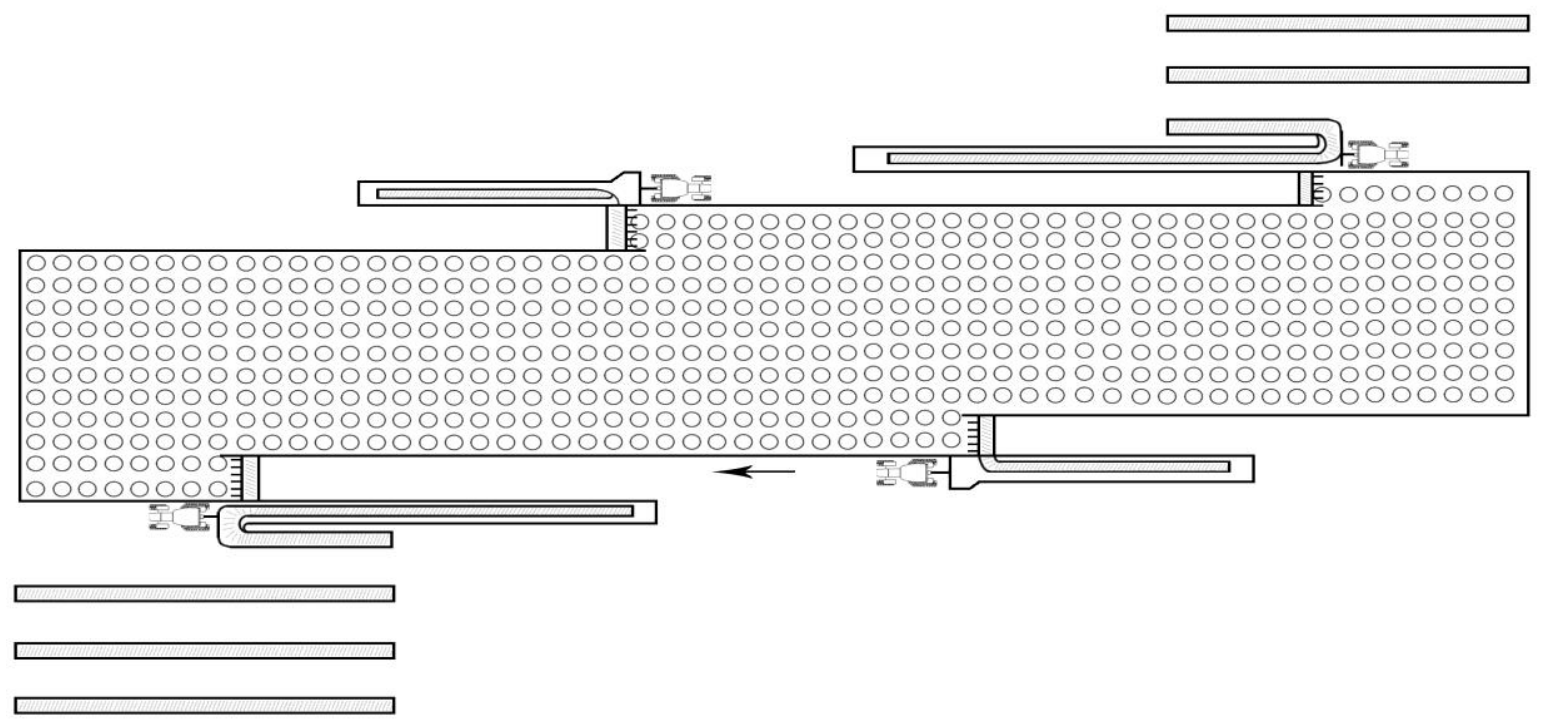

Рис. 3. Схема фрормування валка стрічковими накопичувачами

Виділимо наступні технології збирання усього біологічного врожаю конопель.

1. Технології збирання конопле стеблової маси на стрічкові накопичувачі:

1.1. На насіння і волокно:

- скошування і укладання маси на стрічку;

- фрормування валка стебел коноплі із прогнозованими параметрами;

- вивантаження валка на грунт;

- підбирання і обмолочування насінникової частини;

- транспортування насіння на пункти перероблення;

- укладання стебел у валок для приготування трести;

- обертання стебел;

- підбирання і пресування стебел у тюки;

- навантаження і транспортування тюків на пункти первинної переробки.

1.2. На насіння і волокно:

- скошування і укладання маси на стрічку;

- фрормування валка стебел коноплі із прогнозованими параметрами;

- обмолочування насіннєвої частини стебел стаціонарними молотарками;

- транспортування насіння на пункти перероблення;

- укладання стебел на стрічку з метою приготування трести;

- вивантаження стебел у валок на грунт;

- обертання стебел;

- підбирання і пресування стебел у тюки;

- навантаження і транспортування тюків на пункти первинної переробки.

1.3. На насіння, листостебельну масу i волокно:

- скошування і укладання маси на стрічку;
- фоормування валка стебел коноплі із прогнозованими параметрами;

- обмолочування насіннєвої частини стебел стаціонарними молотарками;

- транспортування насіння на пункти перероблення;

- відділення листя від стебел;

- накопичення маси листя і його транспортування на пункти перероблення;

- укладання стебел на стрічку з метою приготування трести;

- вивантаження стебел у валок на грунт;

- обертання стебел;

- підбирання і пресування стебел у тюки;

- навантаження і транспортування тюків на пункти первинної переробки.

1.4. На листостебельну масу і волокно

- скошування і укладання маси на стрічку;

- формування валка стебел коноплі із прогнозованими параметрами;

- відділення листя від стебел;

- накопичення маси листя і його транспортування на пункти перероблення;

- укладання стебел на стрічку з метою приготування трести, або транспортування стебел на пункти приготування трести;

- вивантаження стебел у валок на грунт;

- обертання стебел;

- підбирання і пресування стебел у тюки;

- навантаження і транспортування тюків на пункти первинної переробки

2. Технологія збирання насіннєвої частини врожаю прямим комбайнуванням та накопичення конопле стеблової маси на стрічкових накопичувачах.

2.1. На насіння і волокно:

- обмолочування насіннєвої частини ; 
- вивантаження насіння і транспортування на пункти подальшої переробки;

- накопичення і вивезення обмолоченої частини;

- скошування стебел, що залишилися та їх укладання на стрічковий накопичувач;

- фрормування валка стебел коноплі із прогнозованими параметрами;

- вивантаження валка на грунт;

- укладання стебел у валок для приготування трести;

- обертання стебел;

- підбирання і пресування стебел у тюки;

- навантаження і транспортування тюків на пункти первинної переробки.

2.2. На насіння, листостебельну масу і волокно

- обмолочування насіннєвої частини ;

- вивантаження насіння і транспортування на пункти подальшої переробки;

- накопичення і вивезення обмолоченої частини;

- скошування стебел, що залишилися та їх укладання на стрічковий накопичувач;

- відділення листя від стебел у стаціонарних умовах на краю поля;

- накопичення маси листя і його транспортування на пункти перероблення;

- укладання стебел на стрічку з метою приготування трести, або транспортування стебел на пункти приготування трести;

- вивантаження стебел у валок на грунт;

- обертання стебел;

- підбирання і пресування стебел у тюки;

- навантаження і транспортування тюків на пункти первинної переробки.

3. Технології збирання врожаю прямим комбайнуванням жниварками 3 дворівневим незалежним скошуванням.

3.1. На насіння і волокно:

- скошування і обмолочування насіннєвої частини врожаю;

- вивантаження насіння і транспортування на пункти подальшої переробки;

- накопичення і вивезення обмолоченої частини врожаю;

- скошування стебел, що залишилися після збирання насіння та їх укладання на стрічковий накопичувач;

- формування валка стебел коноплі із прогнозованими параметрами;

- вивантаження валка на грунт;

- укладання стебел у валок для приготування трести;

- обертання стебел;

- підбирання і пресування стебел у тюки;

- навантаження і транспортування тюків на пункти первинної переробки.
3.2. На насіння, листостебельну масу і волокно

- скошування і обмолочування насіннєвої частини врожаю;

- вивантаження насіння і транспортування на пункти подальшої переробки;

- накопичення і вивезення обмолоченої частини;

- скошування стебел, що залишилися та їх укладання на стрічковий накопичувач;

- підтягування стрічки та відділення листя від стебел у стаціонарних умовах на краю поля;

- накопичення маси листя і його транспортування на пункти перероблення;

- укладання стебел на стрічку з метою приготування трести, або транспортування стебел на пункти приготування трести;

- вивантаження стебел у валок на грунт;

- обертання стебел;

- підбирання і пресування стебел у тюки;

- навантаження і транспортування тюків на пункти первинної переробки.

Деякі операції, в залежності від конструкції технічних засобів для їх здійснення, виконують одночасно механізмами або машинами, що входять в один збиральний агрегат. Технології збирання всього біологічного врожаю закінчуються (умовно) порівняльними станами і положеннями В просторі продуктів збирання. Наприклад, насіння повинно бути доставлено на тік і доведено до товарних кондицій, а не зернову частину врожаю направлено на подальшу переробку.

Стрічкові транспортуючі пристрої і технічні прийоми, подібні описаним, можуть також знайти застосування за умов збирання врожаю зернових, овочів, ягід та ін. культур. За умов збирання овочів і ягід стрічку розстеляють між рядками. Укладені на неї овочі або ягоди транспортують разом зі стрічкою до краю поля, де здійснюється сортування та укладання продукції у відповідну тару. Після звільнення стрічку згортають у рулон.

Основні характеристики стрічки узгоджують з її призначенням та умовами роботи.

\section{Висновки.}

1. Запропоновано спосіб формування валка конопле стеблової маси на стрічку і волочіння її разом з валком до краю поля, що уможливлює суттєве підвищення ефективності механізованих процесів збирання і подальшого перероблення усього біологічного врожаю конопель, льону та інших культур.

2. Розроблено сукупність змістів основних варіантів (розгалужень) систем технологій збирання усього біологічного врожаю конопле стеблової маси на стрічкові накопичувачі, якими враховано технічні, технологічні та економічні передумови реалізації основних технологічних операцій, властивих відповідним технологіям. 
3. Запропоновано спосіб формування на стерні валків із заданою масою стебел на одному погонному метрі. Суть способу полягає в тому, що скошену конопле стеблову масу укладають у вигляді валка на стрічку, яку відпускають зі швидкістю меншою швидкості руху жнивного агрегату. Завдяки цьому уможливлюється накопичення на незначній частині поля по кінцях гону усього обсягу врожаю конопле стеблової маси.

\section{Література}

1. Довідник конопляра / І.О. Маринченко, Ю.В. Мохер, І.М. Лайко та інш., - Глухів: ІЛК HAAH, 2018. - 32c.

2. Розвиток наукових основ створення інноваційних технологій первинної переробки луб'яних культур: дис.... докт. техн. наук: 05.18.01 / Р. Н. Гілязетдінов, Херсон, ХНТУ, 2009. - 329 с.

3. . Sheichenko V., Development of technology for the hemp stalks preparation / I. Marynchenko,, V. Shevchuk, ,N. Zadosnaia // (Book Chapter) Modern Development Paths of Agricultural Production: Trends and Innovations, 2019, https://www.scopus.com/authid/detail.uri?authorld $=57217024503$

4. Шейченко В. Готуємо тресту конопель / I. Маринченко, С. Коропченко // The Ukrainian Farmer, журнал/ щомісячник, 2016. - №9 (81) C.134-135.

5. Шейченко В. Исследование качения катка с рифами в продольно-вертикальной плоскости при взаимодействии с стеблями конопли / I. Маринченко // Motrol Commission of Motorization and energetic in agriculture an international Journal on operation of farm and agri-food industry Machinery, Vol. 18, No.3, Lublin-Rzeszow, 2016. - C. 90-96.

6. Коропченко С. П. Шляхи удосконалення технології збирання та переробки насіннєвих конопель / Р.Н.Гілязетдінов, П.В.Лук'яненко та ін. // Легка промисловість, 2006. - № 2 - С. 46-47.
7. Макаев В.І. Механізація збирання зеленцевих посівів конопель / П.В.Лук'яненко, Р. Н. Гілязетдінов // Сільськогосподарські машини: зб. наук. пр. Луцький держ. техн. ун-т, Луцьк, Ред.-вид. відділ ЛДТУ, 2006. - Вип. 14. - С. 130-137.

\section{References}

1. Marynchenko, I. O. et al (2018), Dovidnyk konopljara. Ghlukhiv: ILK NAAN, 32 p.

2. Ghiljazetdinov, R. N. (2009), "Rozvytok naukovykh osnov stvorennja innovacijnykh tekhnologhij pervynnoji pererobky lubjanykh kuljtur", D. Sc. Thesis, 05.18.01, KhNTU, Kherson, Ukraine.

3. Sheichenko, V., Marynchenko, I., Shevchuk, V. and Zadosnaia, N. (2019) "Development of technology for the hemp stalks preparation" Modern Development Paths of Agricultural Production, Springer, pp. 223-232 https://doi.org/10.1007/9783-030-14918-5_24

4. Shejchenko, V, Marynchenko, I. and Koropchenko. S. (2016), "Ghotujemo trestu konopelj", The Ukrainian Farmer, 9 (81), pp.134-135.

5. Sheychenko, V. and Marinchenko, I. (2016), "Issledovanie kacheniya katka s rifami v prodolnovertikalnoy ploskosti pri vzaimodeystvii s steblyami konopli", Motrol Commission of Motorization and energetic in agriculture an international Journal on operation of farm and agri-food industry Machinery, vol 18, no. 3, Lublin-Rzeszow, pp. 90-96.

6. Koropchenko, S. P. et al (2006), "Shljakhy udoskonalennja tekhnologhiji zbyrannja ta pererobky nasinnjevykh konopelj", Leghka promyslovistj, 2, pp. 46-47.

7. Makaev, V. I., Lukjanenko, P. V. and Ghiljazetdinov, R. N. (2006) "Mekhanizacija zbyrannja zelencevykh posiviv konopelj", Siljsjkoghospodarsjki mashyny: Zb. nauk. st, 14, pp. 130-137.

\title{
Аннотация
}

\section{Обоснование систем технологий уборки биологического урожая конопли}

\author{
В.В. Шевчук, В.А. Шейченко, С.Ю. Проценко, В.М. Гак, Н.Н. Кордубан
}

Исследованы пути повышения эффрективности механизированных технологических процессов убоки всего объема биологического урожая конопли и льна благодаря использованию ленточных накопителей.

Предложен способ формирования валка из стебель конопли на ленту с подтягиванием ее к краю поля, благодаря чему создаются условия существенного повышения эффективности механизированных процессов уборки и дальнейшей переработки всего биологического урожая конопли, льна и других культур.

Разработаны совокупности смыслов основных вариантов (разновидностей) систем технологий уборки всего биологического урожая коноплестебельной массы на ленточные накопители, которыми учтены технические, технологические и экономические предпосылки реализации основных технологических операций, свойственных соответствующим технологиям.

Предложен способ формирования на стерне валков с заданной массой стеблей на одном погонных метров. Суть способа заключается в том, что скошенную коноплестебельную массу укладывают в виде валка на ленту, которую отпускают со скоростью меньшей скорости движения уборочного агрегата. 
Благодаря этому создаются условия накопления на незначительной части поля по концам гона всего объема урожая коноплестебельной массы.

Предложено качественно новый технологический процесс, в котором не молотилка (комбайн) со средствами ее технологического обслуживания перемещается по полю с целью загрузки конопле стеблевой массой, а конопле стеблевой масса в виде валка подается в молотилку. Благодаря реализации отмеченного технологического процесса становится возможным операции обмолота семенной части урожая, обрезания листьев от стеблей, формирование стеблей с целью их дальнейшей переработки в тресту, осуществлять полустационарными комплексами машин на краю поля.

Ключевые слова: промышленная конопля, уборка конопли, фразы спелости, ленточные накопители.

Abstract

Justification of technology systems for harvesting biological hemp harvest V.V. Shevchuk, V.A. Sheichenko, S.Yu. Protsenko, V.M. Gak, N.N. Korduban

The ways of increasing the efficiency of mechanized technological processes, the waste of the entire volume of biological yield of hemp and flax, due to the use of tape drives are investigated.

A method of forming a swath from a hemp stalk onto a tape and pulling it to the edge of the field is proposed, thereby creating conditions for a significant increase in the efficiency of mechanized harvesting and further processing of the entire biological harvest of hemp, flax and other crops.

A set of meanings of the main options (varieties) of systems of technologies for harvesting the entire biological crop of hemp mass on tape drives have been developed, which take into account the technical, technological and economic prerequisites for the implementation of the main technological operations inherent in the corresponding technologies.

A method of forming rolls on a stubble with a given mass of stems per running meter is proposed. The essence of the method lies in the fact that the mown hemp mass is laid in the form of a roll on a belt, which is released at a speed lower than the speed of the harvesting unit. Thanks to this, conditions are created for the accumulation on a small part of the field at the headlands of the entire volume of the hemp crop.

A qualitatively new technological process is proposed, in which not a thresher (harvester) with the means of its technological maintenance moves across the field in order to load the hemp with stem mass, and the hemp mass in the form of a roll is fed into the thresher. Thanks to the implementation of the noted technological process, it becomes possible to thresh the seed part of the crop, cut leaves from stems, form stems for their further processing in a trust, and carry out semi-stationary machine complexes at the edge of the field.

Keywords: industrial hemp, hemp harvesting, ripeness phases, tape drives.

Бібліографічне посилання/ Bibliography citation: Harvard

Shevchuk, V. V. et al. (2020) 'Justification of technology systems for harvesting biological hemp harvest', Engineering of nature management, (2(16), pp. $113-119$.

Подано до редакції / Received: 12.08.2020 